\title{
Pakshaghat and its Management through Panchakarma: A Case Study
}

\author{
Research Article
}

\section{Kritika Thakur¹, Sangeeta H Toshikahne2*, Dinesh Patil ${ }^{3}$, Shikha Desai ${ }^{4}$}

\author{
1. PG scholar, 2. Professor and HOD, 3. Associate Professor, 4. PG scholar, \\ Department of Panchakarma, Parul University, Parul Institute of Ayurveda, Vadodara, Gujarat, India.
}

\begin{abstract}
Vata among tridosha is considered as the controller of everything in the Sharira. Vitated Vata itself effects the Dusyas which pervades the entire body or a part of it and gives rise to different types ailment is called Vatavyadhi. Pakshaghata is one of the important diseases of such criteria which is popularly known as Hemiplegia. A 60 years old male Patient, K/C/O of HTN Since 3 year \& Stroke 3 Months ago complaining of Kinchita Vak-Aspastata (incomplete speech), Bhar-Vruddhi (Heaviness of left limbs), Vama bahu Karma alpata (Left upper limb weakness), Vama amsha sandhi stabhata (Left shoulder stiffness) since 3 Month. Patient was on various treatment methods for the past 2 months but did not get complete improvement. He came to Parul Ayurveda Hospital. The patient was treated with Panchakarma procedure, Shamana Aushadhi and Physiotherapy. This study shows the effective result of Panchakarma treatment along with Shamana Aushadhi and Physiotherapy in Pakshaghata disease. It also helps to understand the pathophysiology of Pakshaghata through Ayurveda. In this study an attempt has been made to describe all Scientific effect of Panchakarma procedures, Shaman Aushadhis and effect of Physiotherapy has been explained in this case.
\end{abstract}

Key Words: Pakshaghata, Panchakarma procedure, Shamana aushadhi.

\section{Introduction}

Pakshaghata is one among the vatavyadi, considered under astamahagada, which is swabhavatahduschikitsya. When the greatly aggravated vata invades the urdhwa, adha and thiryakgatadhamanis, then it destroys any one half of the body which is called as pakshaghata. By this, affected side of the body becomes incapable of any work. Basti is considered as best treatment in Vatavyadhi, but for pakshaghata sneha is the line of treatment. Acharya Charaka also explained swedana and Sneha yukta virechana in pakshagata (1). The synnonyms of Pakshaghata are Pakshavada, Ekangaroga and Sarvangaroga (2). This condition of Pakshaghata can be correlated with the Hemiplegia in the modern science as majority of symptoms are same. This disease is also called as Paralysis in Layman language. It affects the one-half side of body mainly including upper limb and lower limb. Many times, it also affects the functions of speech and facial muscles. Mainly due to stroke or interruption of blood supply to the brain causes Hemiplegia. The one of the leading causes of disability and death in India is the Stroke. The prevalence of stroke in our country ranges from 40-270

* Corresponding Author:

Sangeeta H Toshikahne

Professor and HOD,

Department of Panchakarma,

Parul University, Parul Institute of Ayurveda,

Vadodara, Gujarat, India, India.

Email Id: sangeeta.toshikhane26791@paruluniversity.ac.in per 100000 population (3). On the basis of morbidity out of all cases $45 \%$ patients of stroke can live independently, $22 \%$ patients become dependent on others and $20 \%$ patients' needs admission in hospitals (4). There are mainly two types of stroke. Ischemic and Hemorrhagic. Ischemic stroke is more common than Hemorrhagic stroke. Due to interruption of blood supply Ischemic strokes take place, while Hemorrhagic strokes are the ones which results from rupture of blood vessels or an abnormal vascular structure (5).

In the present case study, the treatment was done for the ischemic stroke. Such conditions can be managed by Ayurvedic treatment and it shows very effective results in acute conditions also. Panchakarma is one of the key treatments for diseases like Pakshaghata. In this case study treatment like Bahya Rukshana karma followed by Bahya snehana, Classical Virechana, Physiotherapy was given along with some Shamana Aushadhis.

\section{Case Study}

A male patient of 60 years old, appeared in Parul Ayurved Hospital Panchakarma-OPD (OPD NO 20020944) on 9/12/2020 with the chief complaint of:

Weakness in left upper and lower limb

Pain and stiffness in left Shoulder joint.

Difficulty while raising left arm

\section{since 3}

months

\section{Associated complaints}

- Pain in low back region since 2-3 weeks

- Headache

At the time of admission patient was conscious and well oriented. 
Past history

- H/O Hypertension Since2 years- On medication Since 3 years (Tab Atenolol IP 50 mg 1-0-0 A/F)

- H/O CVA Stroke 3 Months back (Tab Atorvastatin 40mg 0-0-1 A/F)

- Not K/C/O -Allergy, Typhoid, Malaria, Dengue.

- No H/O - Trauma or Accidental Injury

On Examination

- General condition: Moderate

- Pulse Rate: $75 / \mathrm{min}$

- BP: $140 / 80 \mathrm{~mm}$ of $\mathrm{Hg}$

- RR: $18 / \mathrm{min}$

- HR: 76/min

- Mala: Samyak

- Kostha: Mrudu

- Mutra: Regular

- Nidra: Sound

- Kshudha: Samyak

- Jihva: Liptha

\section{Central Nervous System Examination HMF-Higher Mental Function}

\begin{tabular}{|c|c|c|}
\hline \multicolumn{2}{|c|}{ Consciousness } & Fully C \\
\hline \multirow{3}{*}{$\begin{array}{l}\text { Orientation } \\
\text { to }\end{array}$} & Time & \multirow{3}{*}{ Intact } \\
\hline & Place & \\
\hline & Person & \\
\hline \multirow{3}{*}{ Memory } & Immediate & \multirow{3}{*}{ Intact } \\
\hline & Recent & \\
\hline & Remote & \\
\hline \multicolumn{2}{|c|}{ Hallucination and Delusion } & Absent \\
\hline \multicolumn{2}{|c|}{ Speech disturbance } & Absent \\
\hline \multirow{2}{*}{\multicolumn{2}{|c|}{$\begin{array}{l}\text { Handedness } \\
\text { Cranial Nerve Examination }\end{array}$}} & Right \\
\hline & & \\
\hline Olfactory & Smell sensation & Intact \\
\hline Optic & Color vision & NAD \\
\hline
\end{tabular}

\section{Oculomotor, Trochlear, Abducent Nerve}

Eye ball movement

Possible in all directions

\begin{tabular}{|c|c|}
\hline \multirow{4}{*}{ Pupil } & Position \\
\hline & Shape \\
\hline & Size \\
\hline & Symmetry \\
\hline \multirow{2}{*}{\multicolumn{2}{|c|}{$\begin{array}{l}\text { Ptosis } \\
\text { Trigeminal }\end{array}$}} \\
\hline & \\
\hline Sensory & $\begin{array}{l}\text { Touch, Pain and } \\
\text { pressure sensation }\end{array}$ \\
\hline \multirow{4}{*}{ Motor } & Clenching of teeth \\
\hline & $\begin{array}{l}\text { Lateral movement } \\
\text { of Jaw }\end{array}$ \\
\hline & $\begin{array}{l}\text { Forehead } \\
\text { frowning }\end{array}$ \\
\hline & Eyebrow raising \\
\hline
\end{tabular}

\begin{tabular}{|c|c|c|}
\hline \multirow[t]{3}{*}{ Facial } & Eye closure & $\begin{array}{l}\text { Possible, Equal in } \\
\text { both sides }\end{array}$ \\
\hline & Teeth showing & Normal \\
\hline & Blowing of cheek & Possible \\
\hline \multicolumn{3}{|c|}{ Glossopharyngeal and Vagus } \\
\hline & Position of uvula & Centrally placed \\
\hline & Taste sensation & Intact \\
\hline & Gag reflex & Normal \\
\hline
\end{tabular}

Possible, Equal in both sides

Possible, Equal in both sides

\section{Hypoglossal}

\begin{tabular}{|c|c|c|}
\hline & $\begin{array}{l}\text { Protrusion of } \\
\text { tongue }\end{array}$ & $\begin{array}{l}\text { Complete } \\
\text { protrusion } \\
\text { possible }\end{array}$ \\
\hline & $\begin{array}{l}\text { Tongue } \\
\text { movements }\end{array}$ & Possible \\
\hline \multicolumn{3}{|l|}{ Motor } \\
\hline \multicolumn{2}{|c|}{ Involuntary Movements } & Absent \\
\hline $\begin{array}{l}\text { Muscle } \\
\text { Bulk }\end{array}$ & RT & $\mathbf{L T}$ \\
\hline Biceps & $27.5 \mathrm{~cm}$ & $26.5 \mathrm{~cm}$ \\
\hline Forearms & $24.5 \mathrm{~cm}$ & $23 \mathrm{~cm}$ \\
\hline Mid-thigh & $45.5 \mathrm{~cm}$ & $45 \mathrm{~cm}$ \\
\hline Calf muscle & $30.5 \mathrm{~cm}$ & $29.5 \mathrm{~cm}$ \\
\hline $\begin{array}{l}\text { Muscle } \\
\text { Tone }\end{array}$ & RT & $\mathbf{L T}$ \\
\hline Upper limb & $\mathrm{N}$ & Нуро \\
\hline $\begin{array}{l}\text { Lower } \\
\text { Limb }\end{array}$ & $\mathrm{N}$ & $\mathrm{N}$ \\
\hline Power & RT & LT \\
\hline Upper Limb & 5 & 4 \\
\hline Lower limb & 5 & 5 \\
\hline
\end{tabular}

\section{Coordination}

\begin{tabular}{|c|c|c|}
\hline & Upper limb & $\begin{array}{l}\text { Finger nose test } \\
\text { coordination } \\
\text { present }\end{array}$ \\
\hline & Lower limb & Knee heel test \\
\hline \multicolumn{2}{|l|}{ Gait } & Normal \\
\hline \multicolumn{3}{|l|}{ Reflex } \\
\hline \multicolumn{3}{|l|}{ Superficial } \\
\hline \multicolumn{2}{|c|}{ Abdominal reflex } & Present \\
\hline $\begin{array}{l}\text { Deep } \\
\text { Reflex }\end{array}$ & RT & LT \\
\hline Biceps jerk & Normal & Diminished \\
\hline Triceps jerk & Normal & Diminished \\
\hline Knee jerk & Normal & Normal \\
\hline Ankle jerk & Normal & Normal \\
\hline $\begin{array}{l}\text { Clonus - } \\
\text { Patella }\end{array}$ & Absent & Absent \\
\hline $\begin{array}{l}\text { Clonus - } \\
\text { Ankle }\end{array}$ & Absent & Absent \\
\hline $\begin{array}{l}\text { Babinski } \\
\text { reflex }\end{array}$ & Absent & Absent \\
\hline
\end{tabular}

\section{Sensory System}

\section{Superficial}

Touch

Temperature

Intact

Pain

Intact

Deep

Crude touch

Intact

Vibration

Present

Pressure sense

Present

Present 


\begin{tabular}{|c|l|c|c|}
\hline \multicolumn{3}{|c|}{ Table 1: Observation } \\
\hline Sr. No & \multicolumn{1}{|c|}{ Signs and Symptoms } & Before Treatment & After treatment \\
\hline 1 & Facial deviation & No & No \\
\hline 2 & Shoulder elevation & No & No \\
\hline 3 & Sensory Aphasia & No & No \\
\hline 4 & Trunk balance & No & Yes \\
\hline 5 & Elbow-flexion -extension & No & Yes \\
\hline 6 & Forearm supination-pronation & No & Yes \\
\hline 7 & Wrist flexion-extension & No & Yes \\
\hline 8 & Grip power & No & Yes \\
\hline 9 & While no initiation Holding of object & No & Yes \\
\hline 10 & Grasp objects & No & Yes \\
\hline 11 & Release of object & No & Yes \\
\hline 12 & Catching of object & No & Yes \\
\hline 13 & Throwing of object & Yes & Yes \\
\hline 14 & Tying the knot & No & Yes \\
\hline 15 & Clothing & No & Yes \\
\hline 16 & Feeding with hand & Yes & Yes \\
\hline 17 & Holding and drinking glass of water & Yes & Yes \\
\hline 18 & Standing without support & No & Yes \\
\hline 19 & Standing balance & No & Yes \\
\hline 20 & Squatting & No & Yes \\
\hline 21 & Getting up from squatting position & Yes & Yes \\
\hline 22 & Climbing the stairs & Yes & Yes \\
\hline 23 & Toilet activity & No & Yes \\
\hline 24 & Bathing & Yes & No \\
\hline 25 & Crossing the road & & \\
\hline 26 & Tingling sensation & & \\
\hline & & & \\
\hline
\end{tabular}

Table 2: Muscle power

\section{BEFORE TREATMENT}

\begin{tabular}{|c|c|} 
SR NO. & Extremities \\
\hline 1 & Rt. Upper Limb \\
\hline 2 & Rt. Lower Limb \\
\hline 3 & Lt. Upper Limb \\
\hline 4 & Lt. Lower Limb \\
\hline
\end{tabular}

\section{Grades}

5- Normal Power

5-Normal Power

4-Movement against gravity and some resistance.

4- Movement against gravity and some resistance.

\section{AFTER TREATMENT}

\section{Extremities}

Rt. Upper Limb

Rt. Lower Limb

Lt. Upper Limb

Lt. Lower Limb

\section{Grades}

5- Normal Power

5- Normal Power

4-Movement against gravity and some resistance.

5- Normal Power

Table 3: Intervention

\section{Date}

10-12-2020 to $12-12-2020$

$12-12-2020$ to $18-12-2020$

19-12-2020 to 21-12-2020

22-12-2020 to $24-12-2020$

\section{Shamana}

- Aampacak vati-2-0-2 B/F

- Tapyadi loha-2BDA/F

- Cap Palsineuron 2BD A/F

- Sutshekar rasa 2BD A/F

- Phalatrikadi Kashaya- $30 \mathrm{ml}$ BD B/F

- Pathyadi kashya $30 \mathrm{ml} \mathrm{BD} \mathrm{B/F}$

- Aampacak vati-2-0-2 B/F

- Sutshekar rasa 2BD A/F

- Phalatrikadi Kashaya- 30 ml BD B/F

- Pathyadi kashya $30 \mathrm{ml} \mathrm{BD} \mathrm{B/F}$

\section{Shodhana}

- Sarvanga Udvarttana with Yava Lotta + Triphala churna followed by Nadi sweda.

- Physiotherapy

- Shirodhara with Jatamansi oil.

- Physiotherapy

- Plan for Virechana karma

- Shodhanartha Snehapan with Guggul Tikta ghrita

- Sarvanga Abhyanga with Nirgundi Tail followed by Patra Pinda Sweda 
- Sarvanga Abhyanga with

Nirgundi Tail followed by

Nadi Sweda

- Virechana karma with Trivrut

Avleha -40 gms Anupana

Draksha fanta

Deepana Pachana from 12-12-2020 to 18-12-2020 was done in which Nirama lakshans were observed.

From 19-12-2020 to 21-12-202 Abhyantra Snehapana with Guggul Tikta Ghrita was given to the patients. Until Samyak Snigdha lakshana appears.

Vishrama Kala from 22-12-2020 to 24-12-2020.Sarvnaga Abhyanga with Nirgundi Tail followed by Patra Pinda Sweda.

Table 4: Dose of Snehapana

\begin{tabular}{|l|l|l|l|}
\multicolumn{1}{r|}{ Date } & \multicolumn{1}{c|}{ Intake time } & \multicolumn{1}{c|}{ Dose } & \multicolumn{1}{c|}{ Time of Hunger } \\
\hline $19-12-2020$ & $6: 45 \mathrm{AM}$ & $30 \mathrm{ML}$ & $11: 40 \mathrm{AM}$ \\
\hline $20-12-2020$ & $7 \mathrm{AM}$ & $50 \mathrm{ML}$ & $12: 30 \mathrm{PM}$ \\
\hline $21-12-2020$ & $6: 50 \mathrm{AM}$ & $90 \mathrm{ML}$ & $1: 45 \mathrm{PM}$
\end{tabular}

Daily Jiryamana and Jirna lakshnas were noted. After achievement of Samyak Sneha Lakshana- Abhyanga with Nirgundi Tail followed by Patra Pinda Sweda was done for 3 days.

On Virechan Karma day, first Abhyanga with Nirgundi Tail and Nadi Sweda was given to the patient, before administration of medicine, BP $(130 / 90 \mathrm{~mm}$ of $\mathrm{Hg})$ and pulse $(74 / \mathrm{min})$ was monitored.

For Virechan- Trvrit Lehya (40gm) was given at 10.30am (Shleshma Kal Gate Gyatva).

\section{Anupana}

Draksha Fanta $50 \mathrm{ml}$ was given and Patient was advised to take Luke warm water for whole day. All the instructions were given to the patient e.g., drinking hot water in between Vegas, avoidance of direct air, sleep during day to avoid any complications. A chart was maintained to note down Time of starting of Vegas, contents etc. in the below form:

\begin{tabular}{|c|c|c|c|c|c|c|}
\hline $\begin{array}{l}\text { Time of drug } \\
\text { administration }\end{array}$ & Quantity & Time of Vega & $\begin{array}{l}\text { Contents of } \\
\text { each Vega }\end{array}$ & $\begin{array}{l}\text { Vitals (B.P., } \\
\text { PULSE) }\end{array}$ & $\begin{array}{l}\text { Signs, } \\
\text { Symptoms }\end{array}$ & $\begin{array}{l}\text { Complications if } \\
\text { any }\end{array}$ \\
\hline
\end{tabular}

\section{Observation during Virechana}

1st Vega started at 11:15Am. Last Vega i.e., 16th observed at $7.10 \mathrm{pm}$. It was observed that at constant interval patient had Virechan Vegas up to 5pm. After that frequency decreased. Depending upon observations done during the whole day, below findings were noted:

\section{Table 5}

\begin{tabular}{|l|l|}
\hline Vegiki & Madhyama shuddhi (16 vegas) \\
\hline Lengiki & Samyak Virechan Lakshana \\
\hline Manik & Madhyama \\
\hline Aantiki & Kapha
\end{tabular}

Samsarjana krama was advised after the completion of Virechan procedure. Samsarjana karma was advised for 5 days.

In 1st Annakala Peya was advised. Gradually Ahara was changed (Laghu to Guru), finally normal diet was given in the evening of 5th day. After the completion of Samsarjana krama, Shaman medicine was started to pacify the remaining vitiated Vataadi Dosha.

\section{Discussion}

In an ischemic stroke, there will be reduction in bloody supply to any part of brain tissue, which leads to dysfunction of the that part of brain tissue. About $30-40 \%$ of Ischemic Strokes are termed as Cryptogenic (i.e., one can't be able cause of its origin). Several classification systems for acute ischemic stroke the OCSP i.e., Oxford Community Stroke Project classification (also called as the Bamford or Oxford classification) relies generally on the initial symptoms of stroke, based on the extent of these stroke symptoms, stroke episode is classified as, total anterior circulation infarct (TACI), partial anterior circulation infarct (PACI), lacunar anterior circulation infarct (LACI) or posterior circulation infarct (POCI). These four types of infracts predict the extent of the stroke, the area of the brain affected, the underlying cause and the its prognosis (6).

Due to severe disability and dependency Pakshaghata can be considered as one of the major diseases. Our Acharyas have given the line of treatment for Pakshaghata. In Sushruta Samhita, Acharya has given the treatment protocol in the sequence of Snehana followed by Swedan Mrudu Samshodhana and Basti Chikitsa (7).

In Charaka Samhita, Acharya has given the protocol like Sweda, Sneha, and Virechana (8).

However, in the present study treatment protocol was decided on the basis of the condition of the roga and rogi.

\section{Abhyanga}

Sira Snayu Sankochana is mainly occurs in Pakshaghata hence Snehana is very essential for such condition. By the use of Snehana even the dry wood can bend (9). Abhyanga helps innourishing and strengthening the muscles of upper limb and lower limb. Therapeutically Abhyanga also acts on vitiated Vata Dosha, also it nourishes the Dhatu of the body (10). 


\section{Swedana}

Swedana gives relief from stiffness, heaviness and coldness (11) of body parts and all these symptoms were present in this patient. Generally, Swedana Karma after Senhana Karma is indicated in all kinds of Niramaja Vata roga (12). By the application of Snehana followed by Swedana therapy, the dry stick becomes soft and becomes easy to bend (13), in the same way these Snehana and Swedana Karma gives maximum benefits in conditions like severe spasticity, pain and stiffness, which are commonly present in Pakshaghata cases.

\section{Patra Pinda Sweda}

Leaves of Nirgundi, Ernda, and Arka plants have analgesic and anti-inflammatory properties which are the important ingredient of the procedure. Patra pottali Sweda helps in relieving pain, stiffness and swelling, pacifies the morbidity of Vata, Pitta and Kapha in the affected joints, muscles and soft tissues. In pain related arthropathies before Shodhana like Virechan. Patra Pinda Sweda is effective. When the leaves are fried in the oil the Kleda of leaves goes away (15).

\section{Udvarttana}

Udvartana with Yava + Triphala Churna was selected, as the Udvartana is indicated in Vataja and Kaphaja disorders, it does 'Kaphavilayana' and 'Srotoshodhana' also helps to dissolve the vitiated Meda Dhatu and promotes Agni. The Udvartana is generally administered in Gauravata (heaviness of body), Shula (pain all over body) and Aamaja conditions. The Yava Churna is having properties like Kashaya rasa, Ruksha Guna and Lekhana Karma (16). The Triphala Churna is having properties like Kashaya rasa, Ruksha guna and Tridosha Shamaka,Twachya, Medohara and Deepaniya (17). Hence these both drugs are selected for Udvartana during initial course (1st phase) of treatment.

\section{Shirodhara with Jatamansi tail}

Shirodhara is an ayurvedic method of healing, which helps in relaxing mind, body and soul to a harmonious level. According to Ayurveda, Shirodhara is the ultimate remedy of pacifying the vitiated Vata doshas. The herbal oils used in this treatment balances the nature of the Vata dosha and hence provides relief from the various underlying symptoms of the Vata imbalance (18).

\section{Jatamansi oil}

Jatamansi, also known as "tapaswani" in Ayurveda. It also acts as a brain tonic and helps to improve memory and brain functions by preventing cell damage due to its antioxidant property. It also calms down the brain and manages anxiety as well as insomnia. Jatamansi also helps manage the symptoms of anxiety. According to Ayurveda, Vata governs all the movement and actions of the body and nervous system respectively. Shirashool is mainly due to Vata imbalance. Jatamansi helps reduce shirashool. This is due to its property of Tridosha balancing and a unique Medhya (improve intelligence) effect (19).

\section{Shodhanartha Snehapana}

Shodhanartha Snehapana has three fundamental purposes before Shodhana (purification) processes as follows -

- To prepare the body by bringing the Doshas from Shakha to the Koshtha from where they can be easily expelled out (20).

- To pacify the anticipated provocation of Vata after the purification processes (21).

- For providing strength to the body for bearing the stress of the purification processes (22).

\section{Virechana karma}

Virechana(purgation)described in ayurveda as important aspect of detoxification. Virechana is choice of Sodhana Chikitsa for pitta dushita vyadhi; This study proves efficacy of Virechana in the management of Pakshaghata. The therapy alleviates Vata and purifies the body by removing toxins $(23,24)$.

There is the involvement of Suddha vata prakopa, Anyadosha Samsirsta vata prakopa and dhatukshayajanya vata prakopa in Pakshaghata. As per modern medical science any stroke or shock associated with ischemia and hemorrhage resulting destruction of brain tissue and disturbed blood supply (25-28). Thus, with the help of Virechana Karma vitiated doshas can be expelled out from the body which helps in maintain the equilibrium if the body and reduce the symptoms of the disease.

\section{Nirgundi tail}

Nirgundi leaves are used in Ayurveda for inflammatory swelling of joints, in rheumatism. It has vishaghna (antitoxic), and analgesic action. It is one of the important herbs used in treatment Vata diseases.

A water extract of the leaves, when administered to rats, exhibited anti-inflammatory, analgesic, antihistaminic and membrane stabilizing and antioxidant activities (29). Thus, nirgundi oil having vatahara properties helps to pacify vata and other vata related symptoms.

\section{Pathyadi kashya}

Pathyadi kashaya is an herbal decoction which consist of hareetaki (Terminalia chebula Retz.) and other medicinal herb like vibbhitaki (Terminalia bellerica Roxb.), amalaki (Emblica officinalis Gaertn), bhunimba (Andrographis paniculata), nimba (Azadirachta indica), nisha (Curcuma longa) along with guda (sugar cane jaggery) etc. Pathyadi kashaya is having ushna veerya (hot potency), tridoshahara mainly kaphapitta shamaka and having properties of sheershashulahara (headache alleviating), mala anulomaka (stool formation and facilitated evacuation) and chakshushya (comfort the eye). In the guna paata (verse responsible for clinical applications) of the 
kashaya mentioned that the kashaya has a specific efficacy in shiro roga (head diseases) (30).

\section{Guggulu Tikta Ghrita}

Guggulu tiktaka ghritam contains Tikta rasa pradhana dravyas. Tikta rasa is Pachana (tikta dravya are laghu and ushna tikshan in properties which are very useful for Ama pachna) hence it alleviates Ama (toxic substances) the increased digestive fire helps in maintaining the normal stage of Dhatwagn, so that the body tissues will be in equilibrium state. Tikta rasa helps in formation of Samyak Asthi dathu. (31).

\section{Trivrut avleha}

Trivrut which is most commonly known as Operculina turpethum Linn. The bark of the fresh root is rubbed up with milk and administered as purgative (32). Aruna or Shweta (i.e., having whitish or reddish coloured root) \& Shyama (i.e., having blackish root) are the two varieties of Trivrit. Botanical name of Aruna or Shweta Trivrit is Operculina turpethum (L.) Silva Manso (syn. Ipomoea turpethum), while that of Shyama is Ipomoea petaloides chois (33).

Cardiotonic substance named oleandrin is an active principle of the leaves. The roots, bark and seeds contain cardio-active glycosides, formerly designated as neriodorin, neriodorein and karabin (34).

\section{Aampachaka Vati}

Aam Pachak Vati helpos in reducing aggrevated Tridoshas (Vata, Pitta \& Kapha) and helps digestion by increasing peristaltic movement. This special formulation helps in quickly controlling acidity, flatulence and indigestion is a good remedy for digestive disorders.

\section{Tapyadi loha}

Tapyadi Loha is also used in Pandu and Visha. Rasaushadhi have Rakta Prasadana and Rasayana qualities. Triphala having Deepana Pachana qualities whereas Chitrak, Shunthi, Marich, Pippali and Vidanga are Ushna Virya. Besides Svarna Makshika and Rajat Bhasma show Vishahara properties. Hence, this was the apt choice as the Trial Drug or Vyadhi Viparit Dravya (35).

\section{Cap Palsineuron}

It is a proprietary medicine prepared by combination of Ekangaveera Ras, Mahavatavidhvamsa Ras, Sameer Pannag Ras and Sutasekhara Ras, and all these Yogas are directly indicated in Vataja Roga (36). Due to this specific type of combination, it was administered to patient to tackle symptoms like weakness and stiffness in the muscle.

\section{Sutshekhar rasa}

Sutshekhar rasahelps in improving the vitiated state of pitta and improves the whole digestion and results in proper functioning of Agni. Its substances are having ruksha, laghu, katu and ushna properties that decrease the vitiated drava roopa of pitta (37).

\section{Phalatrikadi Kashaya}

Phalatrikadi kashya consists of Amalaki, Hareetaki, Vibhataki, Amrita, Vasa, Katuki, Kiratikta, Nimba. Phaltrikadi is a most common and famous preparation having properties such as Pittarechak, Yakriduttejak, Deepan, Rechan, Pachak, Shothhara, Jwarahara, Kamala and Panduhara, Yakrit and Raktvikarhara, Tridoshara, Rashayan, Mutrajanana, Pittasarak, Anulomak, Shwedak, Dahaprashaman and Raktapittahara (38)

\section{Physiotherapy}

Physiotherapy is one of the best supportive therapy for the diseases like Hemiplegia. It is very useful for rehabilitation. The main aim of physiotherapy is to treat, correct, prevent and to prepare the patient to adjust with their disabilities and deformities happened (39). In all kinds of Pakshaghata, the physiotherapy is given for the better movements of limbs, fingers and toes.

\section{Conclusion}

Simple Panchakarma treatments are beneficial in conditions like hemiplegia in acute stages. Pakshaghata is a very difficult disease to manage, because complications may arise at any time. But by adopting a proper logical treatment protocol, one can get good results in Pakshaghata. Panchakarma helps muscle restoration and boost motor system and; thus, overall relief in impairment occurs in patient of Pakshaghata. The present case study is a practical evidence for the importance of in balvan patient of hemiplegia. The success of this case helped to gain trust of the patients towards Ayurveda and Panchakarma treatments.

\section{References}

1. Arup Jyoti Das PG Scholar, A Conceptual Study on Pakshaghate Tu Virechanam with Special Reference To Brihatrayee Dept. of SamhitaSiddhanta, Govt. Ayurvedic College, Guwahati-14, Assam.

2. Murthy, K. (2010). AshtangaHridayam (7th ed.,). Varanasi: ChowkhambhaKrishnadas p. 533.

3. Satish, V. (aug 2016). Ayurvedic management of pakshaghat (Right middle cerebral artery hemorrhagic infrarc) A case report. Int. J. Res Ayurveda Pharma Jil, 10. Retrieved from http// dx.doi org/10.

4. Imandas, S., A.S., P., \& Kumar, R. (2016) Clinical evaluation of Basti and Nasya in Pakshaghata (Hemiplegia). PIJAR, 1, 4354th ser. 6. Nanda, B., \& Mandal, A. (n.d.). Stroke (adult hemiplegia).

5. Nanda, B., \& Mandal, A. (n.d.). Stroke (adult hemiplegia) Pg230.

6. Nanda, B., \& Mandal, A. (n.d.). Stroke (adult hemiplegia)Pg 213.

7. Murthy, K., Prof. (n.d.). Sushruta Samhita. (Chapter 5,) Varanasi: Chaukhambha Pg 87.

8. Sharma, R., \& Das, V. (2011). Agnivesha's Charaka Samhita. (Chapter 28,) Varanasi: Chaukhambha Pg 51. 
9. Patil, V. (2017). Principles and practice of Panchakarma (Chapter 8,) New Delhi Chaukhambha Publications Pg 120.

10. Sharma, R., \& Das, V. (2011). Agnivesha's Charaka Samhita. (Chapter 22,) Varanasi: Chaukhambha Pg 388.

11. Sharma, R., \& Das, V. (2011). Agnivesha's Charaka Samhita. (Chapter 22,) Varanasi: Chaukhambha Pg 388.

12. Sharma, R., \& Das, V. (2011). Agnivesha's Charaka Samhita. (Sutra Sthana, Chapter 14) Varanasi: Chaukhambha Pg. 224.

13. Sharma, R., \& Das, V. (2011). Agnivesha's Charaka Samhita. (Sutra Sthana, Chapter14) Varanasi: Chaukhambha Pg 218.

14. Nirmal Bhusal Et Al: Review on Patra Pinda Sweda: A Peculiar Ayurveda Bolus Fomentation. International Ayurvedic Medical Journal \{online\} 2017 \{cited May, 2017\}.

15. Jain R.., Jain P., \& Patil S. (2013). Yava(Barley)Akey to the life style disorder. Ayurpharm Int $J$ Ayur,Pg. 138-143.

16. Shafeer V.M. (2014). Samhita of Ayurvedic medical specialities (3rd ed., p.). Tamil Nadu: $\mathrm{Dr}$ Y.Mahadeva Iyer's Srisarada Ayurveda Hospital Pg 580.

17. Imtiaz Hossain Md, Role of Panchakarma in the Management of Masavritavata w.r.t Dermatomyositis - A Case study

18. Braunwald E, Fanci AS, Hauser SL, Kasper DL, Longo DL, Jameson JL editors; Harrison's Principles of Internal Medicines. 17th edition, Mc Graw-Hill - Medical Publishing Division, New York, 2008: 85.

19. The Ayurvedic Pharmacopoeia of India.Part 1 Volume 1.

20. Charaka Samhita (Ayurveda Dipika Sanskrit commentary). Yadvji Trikamji, editor. 1st ed. Varanasi: Choukhamba Surbharati Prakashan; 1994. Sutrasthana, 28/33, Pg 432.

21. Chakrapanidatta. Ayurveda Dipika commentary on Charaka Samhita, Yadavaji Trikamji, editor.1st ed. Varanasi. Choukhamba Prakashan;1994. Sutrasthana 2/ 15 Pg 53.

22. Vagbhata. Ashtanga Hridayam (Sarvangsundara and Ayurveda Rasayana commentary). Kunte, Navare, Paradkar HS, editors. 7th ed. Varanasi: Chaukhamba Orientalia; 1982.Sutrasthana, Sutrasthana, 18/58 Pg 234.

23. Parul Sharma, Bhushan Sharma and Mohita Bohra, Management of Cerebral Palsy due to HypoxicIschemic Encephalopathy, Through Panchakarma: Case Study, World Journal of Pharmaceutical Research, 2015; 4 (10): 1705.

24. Vivek Kumar Mishra and Neha Mishra, Role Of Panchakarma in Sequential Management of Pranavaha Srotastha Vyadhi in Children, World Journal of Pharmacy and Pharmaceutical Sciences, 2016; 5 (3): 527-538.
25. Charka samhita edited with Vidyotini, Hindi commentary by Pandit Kashinath Panday and Dr. Gorakhnatha Chaturvedi, Chaukhambha Bharti Acadamy, Varanasi, Reprint edition 2008, Sutra sthana, Verse no.20/11, and Pg.399.

26. Susruta Samhita edited with AyurvedaTattwaSandipika, Hindi commentary by Kaviraja Ambika Dutta Shastri, Chaukhamba Sanskrit Sansthan, Varanasi, India, Reprint 2005, Nidana sthana, verse no 01/63, Pg.233.

27. Davidson's Principle \& Practice of Medicine by Nicholas A. Boon, Nicki R. Colledge, Brian R. walker and John A. A. hunter,Chuchill Livingstone Elsevier publication 20th edition 2006, Pg.1200.

28. Astanga Hridaya of Vagbhatta edited with Ayurveda- Vidyotani, Hindi commentary by Kaviraja Atridev Gupt, Chaukhambha Sanskrit Sansthan, Varanasi, India, Reprint 2005, Sutra sthana, verse no. $1 / 25$, and Pg.11

29. Anupama, Nirgundi Tel (oil) for Carbuncle and Joint Disorders,June 27,2017 Pg 1.

30. Henaka, Clinical Efficacy of Pathyadi Kashaya And Thriphala Ghritha In the Management Of Ananthavata With Special Reference To Tension Type Headache.Pg 1-15.

31. Sushruta, sushruta samhita, with the Nibandha Sangraha commentary of Sri Dalhanachary edited by Vaidya Yadavjitrikamji acharya and Narayan Ram acharya translated by PV Sharma, Chaukambha Orientalis, Varanasi, volume 1, Sutrasthana 42 Ndchapter Shloka 3,Pg 386.

32. Nadkarni,K.M. and Nadkarni A.K. 1999 Indian Materia Medica Vol I Popular Prakashan Ltd BOMBAY.,131:965,Pg 16.

33. Srikantha Murty KP, Bhavprakasha of Bhavmishra, volI Chaukhamba Shri Krishna Das, Varanasi, India.,258:259 2008.Pg264.

34. Nadkarni,K.M. and Nadkarni A.K. 1999 Indian Materia Medica Vol I Popular Prakashan Ltd BOMBAY.,131:965,Pg 244.

35. Janki Gajjar, An Evaluation of the Efficacy of Tapyadi Loha in Garavishajanit Pandu, Department of Agadtantra Avum Vidhi Vaidyaka, Bharati Vidyapeeth Deemed University College of Ayurved, Pune, Maharashtra, India J 2016 Greentree Group IJAPC Pharm Chem 2015 Vol. 4 Issue 2 www.ijapc.com 178 [e ISSN 2350-0204]

36. Palsinuron Capsule-Uses,Side-effect,Reviews, and precautions- S G Phyto pharma- Tablet wise Pg13.

37. Thakur J,Sisodia P,A review on the role of sutshekar rasa an effective Ayurvedic formulation for Amlapitta, International Ayurvedic formulation for Amlapitta, International Ayurvedic Medical Journal, November 2018,6(11) 2536-39.

38. Vipin kumar, A critical review of pahaltrikadi kwath wsr to liver disorders, world journal of pharmaceutical and medical research 2017,3(6),100-105.

39. Lohith, B. (2016). A text book of Panchakarma (1st ed.,) Varanasi: Chaukhambha Orientalia Pg 418. 